\title{
Geochemistry of the Namaqualand, Bushmanland and Warmbad melilitite and kimberlite provinces of South Africa and Namibia: the southern extension of the African kimberlitic megalineament
}

\author{
P. E. Janney ${ }^{1 *}$, M.D. Kirchner ${ }^{1}$, P.I. Ogungbuyi ${ }^{1}$, C. Harris ${ }^{1}$, D.R. Bell ${ }^{2}$ \\ ${ }^{1}$ Department of Geological Sciences, University of Cape Town, Rondebosch 7701, South Africa \\ ${ }^{2}$ AEON-ESSRI, Nelson Mandela Metropolitan University, Summerstrand 6031, South Africa
}

\section{Introduction}

The ultimate origin of kimberlites and related igneous rocks, and their potential genetic relationships to deep mantle processes and lithospheric deformation, remains a highly controversial topic of active research (e.g., Nowell et al., 2004; Moore et al., 2008; Jelsma et al., 2009; Torsvik et al., 2010). Globally, most kimberlitic rocks occur as localised clusters that do not show clear age progressions over long distances or form nearly continuous linear zones of volcanism aligned with plate motions analogous to that seen in linear volcanic chains in the ocean basins. A marked exception to this is a remarkable linear zone of NE-SW oriented, largely age-progressive (Early Mesozoic to Early Cenozoic) alkaline magmatism, consisting mainly of diatremes and pipe-like intrusions of kimberlite, carbonatite, melilitite and ultramafic potassic igneous rocks extending from the west coast of South Africa to eastern Zambia (Moore et al., 2008). This lineament extends nearly $2500 \mathrm{~km}$ in length and $\approx 120 \mathrm{~km}$ in width across southern Africa, nearly to the southern end of the East African Rift system. Here we present geochemical results for mafic and ultramafic alkaline igneous rocks from the Namaqualand-Bushmanland Warmbad (NBW) province, in western South Africa and southeastern Namibia, which represents the youngest and densest portion of the megalineament.

\section{Age constraints on the Namaqualand-Bushmanland-Warmbad province}

Mafic/ultramafic alkaline igneous magmatism in the NBW province is concentrated in three dense clusters (Figure 1a): Namaqualand (consisting of roughly 25 pipes, 38-56 Ma; Moore et al. 2008 and references therein, containing olivine nephelinite and melilitite, with minor carbonatite and ultramafic lamprophyre); Bushmanland (consisting of 200-300 pipes, 59 to $80 \mathrm{Ma}$; Moore et al., 2008; Davis et al., 1976; Griffin et al., 2014; fewer than 100 of which are composed of rocks such as olivine melilitite or rare ultramafic lamprophyre, the others being filled with volcaniclastic breccias or sediments) and Warmbad (consisting of approximately 50 Group 1 kimberlite pipes; mainly 60 to 83 Ma; Davis et al., 1976; Griffin et al, 2014; although a few older kimberlites occur in this area).

Age constraints for the NBW province are sparse and in many cases are based on likely unreliable whole-rock K-Ar ages. There are also disagreements in age determinations, most notably for the Rietfontein kimberlite (N. Cape, northernmost in Warmbad cluster) based on U-Pb measurements of kimberlitic zircon $(72 \pm 1 \mathrm{Ma}$; Davis et al., 1976) and perovskite $(134 \pm 9 \mathrm{Ma}$; Griffin et al., 2014). Northeast of the Warmbad kimberlite province, the age progression largely disappears, with most rocks in the megalineament having ages betwen 77 and $113 \mathrm{Ma}$ (ages from compilation of Moore et al., 2008), including the Tsabong-Malopo and Orapa kimberlite provinces in Botswana and the Katete and Kaluwe carbonatites in Zimbabwe and Zambia, respectively.

\section{Geochemistry and petrogenesis}

Fresh, precisely located igneous rock samples have been obtained from 10 Namaqualand melilitite pipes, 13 Bushmanland melilitite pipes and 5 Warmbad lamprophyre/kimberlite pipes extending the length of the NBW province. Whereas the Bushmanland melilitites and Warmbad kimberlites are all near-primary (with Mg\# ranges of 69 to 77 and 78 to 91, respectively), rocks of the Namaqualand cluster (collectively called melilitites, although some do not contain melilite) are mildy to moderately differentiated (with $\mathrm{Mg} \#$ between 71 and 45 ), requiring up to $50 \%$ olivine crystallization. The highly $\mathrm{SiO}_{2}$-undersaturated compositions of the parental magmas result in both $\mathrm{SiO}_{2}$ and $\mathrm{MgO}$ decreasing with increasing fractionation in the Namaqualand melilitites. Although there is no evidence from their chemical or radiogenic isotopic compositions for crustal assimilation, 
olivine separates from some of the Namaqualand melilitites emplaced through the Early Cretaceous Koegelfontein intrusive complex have $\delta^{18} \mathrm{O}$ values as low as $+4.2 \%$ (compared to values of +4.9 to $+5.6 \%$ for the other Namaqualand and Bushmanland melilitites; Day et al., 2014). Koegelfontein is a $\approx 30 \mathrm{~km}$ diameter igneous complex in southern Namaqualand composed of felsic-intermediate intrusive rocks that were emplaced shortly before opening of the South Atlantic and and is notable for containing igneous rocks with remarkably low $\delta^{18} \mathrm{O}$ values (as low as $-4 \%$ ). This indicates that minor crustal assimilation must have occurred in the genesis of at least some Namaqualand melilitites.

Across the three clusters of the NBW province, there are systematic variations in incompatible element contents from the coastal region to the continental interior, most robustly demonstrated by the relative abundances of $\mathrm{Th}, \mathrm{U}$ and $\mathrm{Nb}$. Namaqualand melilitites are relatively enriched in $\mathrm{U}$ and $\mathrm{Nb}$ compared to elements of similar incompatibility and therefore have low $\mathrm{Th} / \mathrm{Nb}$ and $\mathrm{Th} / \mathrm{U}$ ratios relative to primitive mantle (Fig. 1b). However, both of these ratios increase markedly in the Bushmanland melilitites and appear to increase further, though more subtly, in the Warmbad kimberlites. Similarly, there is a systematic progression in terms of radiogenic isotope ratios along the length of the lineament This is most clearly shown in $\mathrm{Pb}$ isotope ratios, which are highest in Namaqualand $\left({ }^{206} \mathrm{~Pb} /{ }^{204} \mathrm{~Pb}_{\mathrm{i}}=19.5\right.$ to 21.1 ; Fig. 2$)$, showing a fairly strong HIMU source affinity, and somewhat lower in Bushmanland $\left({ }^{206} \mathrm{~Pb} /{ }^{204} \mathrm{~Pb} b_{\mathrm{i}}=18.9\right.$ to 20.3). Sr and $\mathrm{Nd}$ isotope ratios in the Namaqualand and Bushmanland clusters are similar $\left({ }^{87} \mathrm{Sr}^{86} \mathrm{Sr}_{\mathrm{i}}=0.7031-0.7036\right.$ (for leached samples), $\varepsilon_{\mathrm{Nd}}(\mathrm{t})=+2.0$ to +5.5 ). The Warmbad kimberlites (carefully picked (and leached for Sr isotopes) to avoid alteration \& contamination) largely overlap with the Bushmanland melilitites in terms of $\mathrm{Nd}$ and $\mathrm{Pb}$ isotope composition (e.g., ${ }^{206} \mathrm{~Pb} /{ }^{204} \mathrm{~Pb}_{\mathrm{i}}=18.6$ to 19.9), but extend to somewhat higher ${ }^{87} \mathrm{Sr}^{86} \mathrm{Sr}_{\mathrm{i}}$ ratios (0.7034-0.7044). Cr-poor and Cr-rich clinopyroxene megacrysts from the Pofadder kimberlites (for which there are no fresh whole-rock samples) span a wide range of isotopic compositions overlapping with the melilitites and kimberlites, though at the lower end of the ${ }^{206} \mathrm{~Pb}^{204} \mathrm{~Pb}_{\mathrm{i}}$ range.
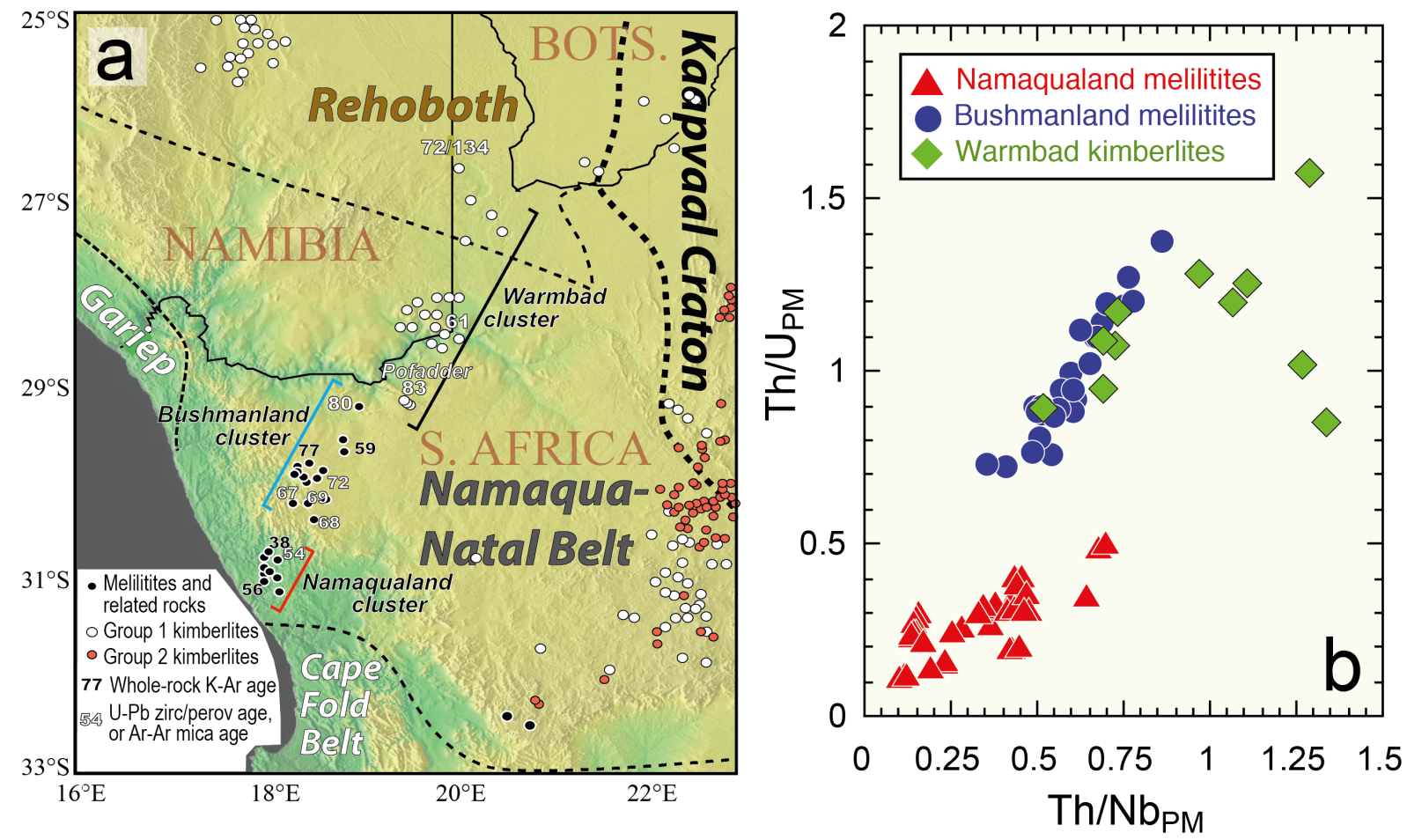

Figure 1. (a) Map of kimberlites and related rocks in southwestern Africa showing location of the NBW province and crustal terrane boundaries. Ages from compilation of Moore et al. (2008), Davis (1976) and Griffin et al. (2014). (b) Primitive mantle-normalised $\mathrm{Th} / \mathrm{Nb}$ vs. $\mathrm{Th} / \mathrm{U}$ ratios in the NBW province rocks.

\section{Discussion}

The geochemical data display a shift in mantle source compositions indicating that the magmas on the thinnest lithosphere in the coastal region (Namaqualand) have the strongest HIMU affinity (extending to exceptionally high ${ }^{238} \mathrm{U} /{ }^{204} \mathrm{~Pb}$ (to more than 500 ) and low $\mathrm{Th} / \mathrm{U}$ values (of less than 
$0.8)$ ), whereas those emplaced on thicker lithosphere toward the continental interior appear to reflect a greater degree of assimilation of ancient metasomatised lithospheric mantle, with sources having lower time-integrated $\mathrm{U} / \mathrm{Pb}$ ratios, and thus lower ${ }^{206} \mathrm{~Pb} /{ }^{204} \mathrm{~Pb}$. This finding is consistent with the pattern expected for southwestern Africa passing over a weak HIMU-type mantle plume. However, the poorly defined age-progression within the megalineament and the lack of evidence for young intraplate volcanism in the southeastern Atlantic Ocean that could be related to it do not offer strong support for a plume origin. Therefore origins for the megalineament relating to lithospheric deformation (e.g., extension or shearing) or lithosphere-asthenosphere interactions cannot be ruled out. Further, recent evidence from megacrysts for the prevalence of strong HIMU signatures in the sources of many Cretaceous southern African kimberlites (Janney and Bell, abs. 4630, this volume) suggests that such HIMU signatures do not necessarily require a mantle plume and could possibly be lithospheric in origin.
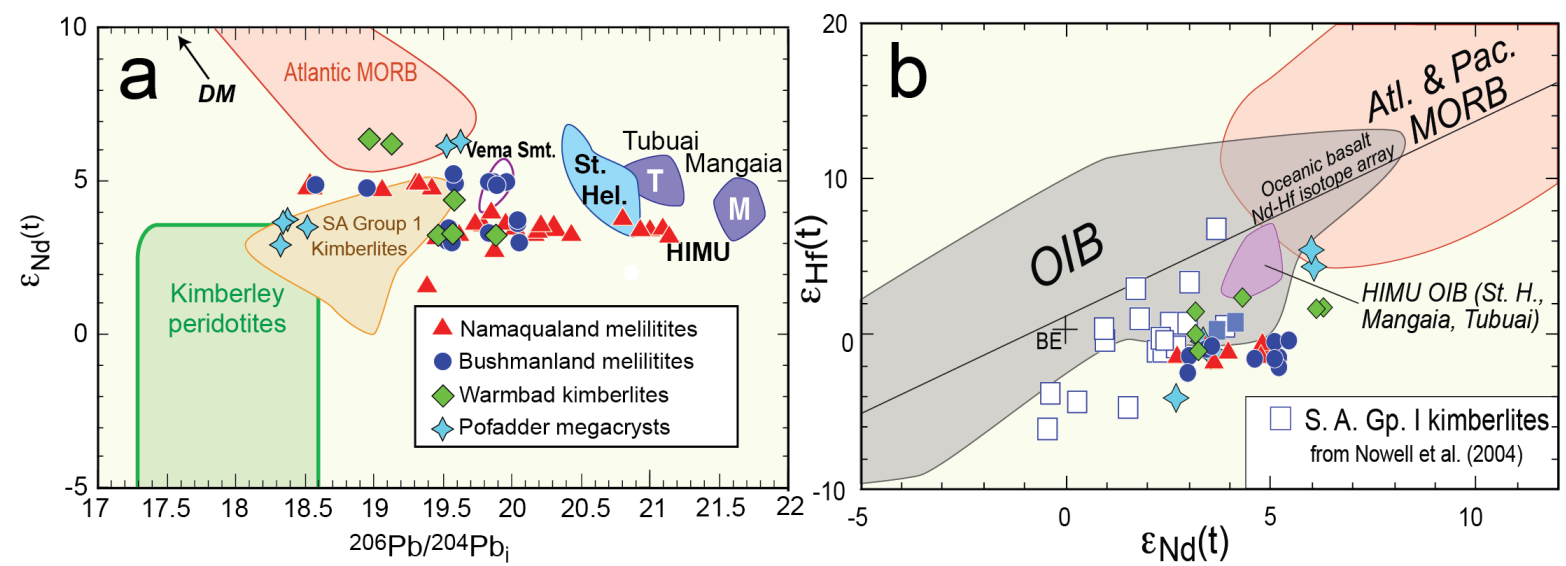

Figure 2. (a) ${ }^{206} \mathrm{~Pb} /{ }^{204} \mathrm{~Pb}_{\mathrm{i}}$ versus $\varepsilon_{\mathrm{Nd}}(\mathrm{t})$ and (b) $\varepsilon_{\mathrm{Nd}}(\mathrm{t})$ versus $\varepsilon_{\mathrm{Hf}}(\mathrm{t})$ for the NBW melilitites and kimberlites, showing fields for MORB, HIMU OIB and other relevant rock types. Data for Grp. I kimberlites from Smith, (1983); Davies et al. (2001) and Nowell et al. (2004). MORB and OIB data from PETDB and GEOROC.

\section{Acknowledgements}

Generous support for this project was provided by the South African National Research Foundation and the UCT Science Faculty to PEJ, and a Council for Geoscience bursary to MDK.

\section{References}

Davies, G. R., Spriggs, A. J. \& Nixon, P. H. (2001). A non-cognate origin for the Gibeon kimberlite megacryst suite, Namibia: Implications for the origin of Namibian Kimberlites. Journal of Petrology 42, 159-172.

Davis, G., Krogh, T. \& Erlank, A. J. (1976). The ages of zircons from kimberlites from South Africa. Carnegie Institution Yearbook 75, 821-824.

Day, J. M. D., Peters, B. J. \& Janney, P. E. (2014). Oxygen isotope systematics of South African olivine melilitites and implications for HIMU mantle reservoirs. Lithos 202, 76-84.

Griffin, W. L., Batumike, J. M., Greau, Y., Pearson, N. J., Shee, S. R. \& O'Reilly, S. Y. (2014). Emplacement ages and sources of kimberlites and related rocks in southern Africa: U-Pb ages and $\mathrm{Sr}-\mathrm{Nd}$ isotopes of groundmass perovskite. Contributions to Mineralogy and Petrology 168, 1032.

Jelsma, H., Barnett, W., Richards, S. \& Lister, G. (2009). Tectonic setting of kimberlites. Lithos 112S, 155-165.

Moore, A. E., Blenkinsop, T. \& Cotterill, F. (2008). Controls on post-Gondwana alkaline volcanism in southern Africa. Earth and Planetary Science Letters 268, 151-164.

Nowell, G. M., Pearson, D. G., Bell, D. R., Carlson, R. W., Smith, C. B., Kempton, P. D. \& Noble, S. R. (2004). $\mathrm{Hf}$ isotope systematics of kimberlites and their megacrysts: New constraints on their source regions. Journal of Petrology 45, 1583-1612.

Smith, C. B. (1983). $\mathrm{Pb}, \mathrm{Sr}$ and $\mathrm{Nd}$ isotopic evidence for sources of southern African Cretaceous kimberlites. Nature 304, 51-54.

Torsvik, T. H., Burke, K., Steinberger, B., Webb, S. J. \& Ashwal, L. D. (2010). Diamonds sampled by plumes from the lower mantle. Nature 466, 352-355. 